\title{
"The Healthful Art of Dancing": Luther Halsey Gulick, Gender, the Body, and the Performativity of National Identity
}

\section{Thomas Winter}

By the early twentieth century, concerns with bodies and the American body politic proliferated with a new interest in physical exercise for men and women, the ideal of a reinvigorated "muscular Christianity," the playground movement, temperance activism, the social hygiene and eugenics movements, to name but a few. At a time when the United States spread its imperial wings, while facing a renewed upsurge in immigration, reformers and political activists shared heightened anxiety and concern with a wide range of body-centered issues which, in their mind, could both promote, or undermine, or even pollute American bodies and the body politic. Through simultaneously shaping and reinvigorating the bodies of native-born Americans and policing the bodies of so-called "new immigrants," these reformers hoped to stabilize and reinvigorate the American body politic (Diner 73-74, 261; Kimmel 177-81, 196; Freedman and D'Emilio 165-66, 203-8, 211-15; Riess 24-26, 138, 142, Budd, esp. 43-54, 64-79, 81-99; Bederman 8, 15, 42; Edwards 153-66). ${ }^{\text {. }}$

This interest in effecting change through shaping the body and this dual concern with social progress and social control was part of Progressive Era reforms. Historians of the Progressive Era have emphasized the often contradictory nature of the reforms and the reformers' motivations. Progressives' desire to reconcile conflicts between individual and community, old ideals and new social realities, often led them to precarious balancing acts between social justice and social control. Torn between a belief in human progress and equally as firm conviction as to the immutability of racial, ethnic, and class differences, Progressives frequently embraced ideas of social control in the attempt to ensure progress and social justice (Rodgers 113-32; Buenker 187-204). In the Progressive Era, social control through physical discipline became understood as a social good by many Americans who hoped to ensure social progress and national cohesiveness.

In 1908, the New York Public Schools joined the choir of body reformers and instituted a folk dance instruction program. The primary goal of the New York program was to teach school-age girls folk dances. Over a course of four years, about 3,000 children in 68 classes and 125 teachers participated. The New York program served as a model for other cities, such as Baltimore, Chicago, and Pittsburgh. By 1910, 17 cities had organized similar programs, linking together concerns with social control, physical health, and the promotion of American values (Tomko 156; Riess 141).

Linda Tomko has investigated these folk dance activities with a focus on the gendered meanings of the instruction program and the role of the female instructors. She argues that "the reciprocal relationship between women and dancing...proved instrumental in women's assertion of professional and political agency" $(156,172)$. Tomko places folk dancing and its instructors in the context of the formation of a "new middle-class," whose political interests grew alongside their professional concerns (Wiebe 111-32).

Scholars have neglected to examine the connections between notions of gender and national identity prevalent in these folk dancing activities. Tomko notes that "a certain American nationalism" (163) was part of the program, and she registers the cultural marginalization of ethnic groups of non-Anglo-Saxon descent through the selection of folk dances designated suitable for the program. Tomko, though, neglects significant implications of folk dance performance for the construction of national identity in connection with the female body. David Glassberg focusses on the ways in which pageants, which often used folk dancing, historicized national identity in a "ritual of social transformation" (Glassberg 4), creating and affirming social hierarchies and national identity. But whereas Tomko underemphasizes the significance of national identity, Glassberg neglects the role of gender in pageantry and folk dancing.

I suggest that men, such as the program's initiator, Luther Halsey Gulick, connected the production of an American national identity to notions of race and the 
generativity of the female body disciplined through folk dance instruction. My argument, then, is twofold.

First, I argue that this folk dance instruction program aimed at reasserting Nordic immigrant cultures with the goal to reinvigorate American national identity, while at the same time selectively assimilating immigrant cultures into an American national character (Duara 151-78; Walby 198-213; Vedery 226-34). Second, I argue that this project of reasserting and reinvigorating an American body politic depended crucially on the female body. National identity often has been perceived as depending on the reproduction of kinship relations, both racial and familial, or sexual (Shell 22-23). This process of reproduction had to rely on bodily generativity. That, in turn, required an identifiable site-- the female body, which is cast as a permeable, perceptive, and accommodating reproductive apparatus (Waldby 268). ${ }^{2}$ By means of folk dance instruction, the female body is being territorialized and subordinated to the culturally reproductive needs of a racialized body politic. In sum, I argue that in the context of Progressive Era folk dance instruction programs in New York City and other American metropolises, national identity functioned as a performative practice, compelled through a gendered and racialized discourse of national identity (Armstrong; Bourdieu 52-66; Butler 12-13; McClintock; Hartsock 155-85; Higham 158-93). ${ }^{3}$

Born on December 4, 1865, in Honolulu as the fifth son of missionaries, the physical educator, author, and YMCA official Luther Halsey Gulick was the architect behind this program of dance education for girls in the New York schools. By the time of his death in 1918, Gulick had made seminal contributions to American physical education. From 1887 to 1903, Gulick served as secretary of the Physical Training Department of the YMCA International Committee. Upon leaving Springfield in 1903, Gulick became director of physical education in the public schools of New York City, where he created the Girl's Branch of the Public Schools Athletic League, and brought folk dances to New York schools. Gulick remained in that position until 1908, when he left his New York post and devoted his time to the Department of Child Hygiene of the Russell Sage Foundation. Failing health forced him to give up that post in 1913 (Hopkins 251-70). In 1911, Gulick published the results of his observations of the New York folk dance program, along with related essays on physical exercise and athletics for women, as The Healthful Art of Dancing (hereinafter HAD).

Proper education in folk dancing, evoking its immigrant heritage, Gulick believed, was especially useful for American society in the early twentieth century. Gulick was convinced that America "is to be the land of the greatest, most potential, and perhaps the last blending of human stock and also of social inheritances." Gulick added that "we are in the midst of a great movement to resurrect the valuable parts of the race inheritances" (HAD 6). Through learning and practicing Bohemian, Danish, English, Finnish, Hungarian, Italian, Norwegian, Russian, Scottish, and, most of all, Swedish folk dances, Americans would be reacquainted with their heritage, while also absorbing and appropriating aspects of so-called "new immigrant" cultures, whereas immigrant girls would be instilled with an Anglo-Saxon heritage. ${ }^{4}$

The folk dance was ideally suited to resurrect past folk traditions and to reinvigorate an American national identity. Gulick felt that the multi-national origins of the American population had actually led to a diminishing of folk traditions. Gulick wrote that "while our American nation includes in it representatives from most of the peoples under the sun, we possess less of the folk music, folk dances, folk lore, folk games, folk festivals of the world than do any of the peoples of which we are made." The reason, Gulick believed, was the process of migration: "the reason lies partly in that these folk expressions are social inheritances carried by a community as a whole; when individuals migrate the social customs are lost" (5). In turn, Gulick believed that America's national identity was particularly well suited for dancing, as it promised to provide an outlet for pent-up emotional energy. In Gulick's own words, "our national temperament, enthusiastic and spontaneous needs just such an outlet for its surplus emotional energy" (29). Moreover, instruction in immigrant folk dances might even allow Americans of Anglo-Saxon background to appropriate some useful features of so-called new immigrant cultures. As Gulick put it, "We AngloSaxons use the language of symbols in muscular movement less than do Southern People" (218-19). The main emphasis, though, was on the reproduction of a specifically American heritage: "The dances are intended to meet the needs of American children; they must relate themselves to American conditions; much of their value would be lost through too strict an adherence to the traditional letter of the performance" (29). Dancing, in Gulick's mind, was ideal for reinvigorating a sense of social belonging and national identity.

By means of the dance, America's national life would gain in richness, Gulick believed. "A country in which the children had been given a chance to develop their natural instinct for rhythmical and har- 
monious activity," Gulick asserted, "would have a national life far richer, deeper, and more beautiful than one where the main emphasis in education was upon bare intellectual training for the purposes of practical success" (30). Through folk dance performance, students would acquire each other's heritage, while also receiving reminders of their own respective background.

Folk dances achieved this goal by linking individual character and self-expression to community functions. Individual character and national character were closely intertwined in Gulick's thinking. Through the means of the dance, the "two deep desires, one for the expression of individual life, and the other for the expression of community life, is coming to consciousness" (196-97). Dancing could achieve this, Gulick believed, because it "united body and soul in the expression of high emotion." Through the dance and its "cadenced rhythms, these expressions of strong and virtuous emotions, that poise-mental as well as physical-becomes wrought into the tissue of character" (xiv). Gulick was convinced that through the dance, individual desire for self-expression and the formation of national identity could be joined. Through folk dancing as a form of organized play, individual desires would be joined into a larger group consciousness.

This phenomenon promised to draw circles far beyond the children. "The parents," Gulick observed, "as they come to school and see their children taking part in the dances of the various races, have come to feel that there exists between themselves, their children and the historic past of their peoples ties which formerly had not been appreciated" (42). Dancing, so Gulick hoped, could serve as an effective tool in forging bonds of community and national identity, based on invoking a mythical, ancestral past-the history of the race. Folk dances were to play a crucial role in weaving the more hardy racial past back into the fabric of a civilized present.

Gulick's thinking about exercise, dance, and civilization built on the so-called recapitulation theory, championed by G. Stanley Hall, which represented the theoretical core of psychology, physical anthropology, and child study at the time. Anthropologists and biologists shared the belief that each individual and each race inherited the history of the human race and on its way to maturity recapitulated past stages of evolution. Since each individual inherited the ancestral past of the race, it was theoretically possible to retrieve it. Folk dances, Gulick believed, encapsulated this mythical ancestral past, ready to be resurrected. Gulick wrote that "the old rhythmical movements which have been found among all the primitive peoples and in all civilizations have crystallized in the dance. These old folk dances express in extraordinarily complete form man's history" (185). Folk dances, from that perspective, were ideally suitable to tap the more hardy racial past and to reinvigorate the body politic without giving up civilized accomplishment (Russett 50-57; Rader 123-34).

Crucial to reinvigorating national identity through the dance was the idea that the movements of the dance, abstractions of the performance of age-old tasks, "necessary to use in...daily occupations" (HAD 210 ), would invoke ancient feelings connected to primordial ideas of survival. Gulick wrote that folk dances emphasized those "neuromuscular coordinations which arose under the selective influences of survival." These "neuromuscular coordinations," Gulick claimed, had been "necessary to the life of the race" (137). Encapsulating the very essence of physical survival, the "neuromuscular coordinations" used "constitute those particular coordinations...in connection with which his intelligence as well as his morality have arisen" (138). Gulick wrote that "those exercises; properly arranged, produced rhythmical movements that are capable of expressing and arousing some of man's deepest and strongest feelings" (210). The dance would reacquaint the dancers not merely with their own culture, while exposing them to immigrant culture as well. More so, folk dancing would infuse the dancer's body with the knowledge of "an ancient racial past," because "the dance gives those racially old coordinations to the individual" (139). Gulick understood racial belonging as a cultural integration of discreet individualities into a cooperative, coherent, harmonious whole on the physical level of the body. The folk dance, then, represented an ideal means of racial revitalization in the context of civilized morality.

However, this was not a conscious act of mind, but an act of emotions, rhythm, and the body, devoid of conscious agency. Gulick wrote that "rhythm is a fundamental principle of life....yet it is not the intellect,...so much as it is the body, the part of us that feels, which responds in the most vivid unison with this principle" $(24,25)$.

This focus on body and feeling required emotional, embodied beings. Nineteenth-century Victorians, prizing emotional expression as the most truthful, because most immediate expression of the self, believed that women were by definition more sincere, because they were physically less capable of hiding their emotions (Halttunen 57-59; Kasson 16061, 180-81). 
The female body appeared to be ideally suited for such a project. In ontogenetic terms, scientists believed that a woman always remained an adolescent, whereas in philogenetic terms, woman represented the ancestral past of the race. Cast as a weakwilled adolescent, then, woman and her body were perceived as malleable and shapable; as representative of the ancestral, racial past, she was the reservoir of so many qualities reformers, such as Gulick, wished to preserve and reinfuse into the body politic (Russett 54-57; Schiebinger 134-42).

Gulick's ideas about gender and national identity were founded in contemporary theories that explained gender differences in terms of the laws of thermodynamics. This concept of the body as a thermodynamic system, outlined by Patrick Geddes and J. Arthur Thomson and explained in their book, The Evolution of Sex (1889), supported notions of sexual difference. The laws of thermodynamics, in short, provided natural scientists with a matrix that enabled them to cast men and women in terms of pre-conceived notions of gender. This matrix assigned the female body the function of accumulating life force through reproduction, while assigning the male body the function of providing this life force. To guarantee the perpetuation of male life force, the female body required careful disciplining, while at the same time writers on the subject advised men to carefully household their sexual potential (Seltzer 29-41; Barker-Benfield 17988; Haller and Haller 195-211). Human bodies had to be shaped according to their allegedly innate gender.

The purpose of dance education, in Gulick's mind, was to shape individuals specific to their respective gender: "character...must be shaped according to the fundamental characteristics of each sex. We do not want womanish men nor mannish women. Each sex must first be fundamentally true to its own kind" (HAD 160).

Gulick's views on physical exercise reflected this view. Physical exercise and athletics were still regarded as a male preserve and a testing ground of manliness. According to Gulick, men "are the survivors of those whose very lives depended upon their ability to run, strike, and to throw." This required men to develop specific "mental and moral qualities of endurance, pluck, team work, fair play...in connection with the playing and earnest use of those activities" (155). As Gulick phrased it, "the best qualities of boyhood and manhood have thus for long ages been both produced and tested by athletic sports, which may be thus considered, to some extent at least, a measure of manhood" (155-56). "Athletics," Gulick insisted, "do not test womanliness as they do test manliness" (157).
In short, Gulick associated athletics with all the qualities that guaranteed survival of the race-and these qualities, in turn, he identified with men (Bederman 77-120; Gorn 179-206; Budd; Rotundo 239-46; Kimmel 117-56).

Women, according to Gulick, had remained domestic, privatized beings-crucial to reproduction, but largely disconnected from the processes and tasks involved with survival of the race. Gulick wrote that "it was not the women who could run, throw, and strike best who survived. The women who were the best mothers, who were most true to their homes, who were the best workers, were those that survived." Therefore, Gulick concluded, "athletics have never been either a test of or a large factor in the survival of women" (HAD 156-57). Women apparently lacked those race traits of cooperation and survival. "The essential need for the girl," Gulick emphasized, "is not to be brave and loyal to the crowd. It is required of her first that she be loyal to the home.... That is the evolutionary stage" (160). Women's confinement to the domestic sphere of the home, Gulick claimed, had restricted them in their social relations, emphasizing their individuality over their capacity for community.

Whereas cooperation for the good of the community, a quality crucial for racial survival, was allegedly part of boys' upbringing and nature, at a time when women became politically increasingly assertive, embracing and shaping a public identity for themselves, girls had yet to receive proper training in Gulick's mind. Gulick believed that "in view of the wide competition with men into which women are coming in the modern world" (147-48), it had become necessary to offer athletic programs for girls as well as boys. Gulick argued that dance education addressed that issue, and "it is believed by the ladies who are directing the work of the Girls Branch that one of the most important lessons which girls need to learn...relates to the nature and advantage of cooperation of team work" (33). Such qualities, in turn, once infused into women's bodies and minds, would be imparted, both through education and reproduction, onto the next generation. Through the dance, national identity is recapitulated, performed, and reproduced as a racialized structure in time.

In the scenario of New York folk dance instruction, the formation and reproduction of an American national identity relied on disciplined, female generativity. At a time when women dancers helped to break down traditional attitudes towards the body (Thomas 47-54), the folk dance movement reinforced those very same traditional attitudes. Through partaking in these folk dances, the increasing public presence of 
women would be channeled towards reinforcing a male-coded, racialized discourse of national identity. Within this discourse, the woman is only body and she can only achieve public identity through the body. This process, though, does not require conscious political agency on her part. Instead it is an unconscious act, driven by emotions invoked through the performance of the dance. The female body, then, serves as a receptacle of a racial past and a site of knowledgea knowledge that she cannot shape or manipulate, but a knowledge that demands to be invoked. Only by invoking this primordial knowledge by means of the dance, does the woman and her body obtain public validity. Her body, in turn, is contained by performative practice consistent with political discourse.

\section{Notes}

'For an introduction to the problems and issues of the history of the body, see Porter (207-32). For theoretical studies on the body in history and society, see, for example, Butler; Foucault (1973, 1975, 1980); Turner; Synott; Shilling.

${ }^{2}$ Mark Seltzer, in his examination of turn-of-the-century American literature, has identified "the desire to project an alternative to biological reproduction, to displace the threat posed by the 'women people'... and to devise a counter-mode of reproduction." This mode of reproduction Seltzer refers to as "the naturalist machine" (32). I, too, see what Seltzer has referred to as a "general economy of bodies and power" (28), but instead of a displacement of female generative power, I see the attempt to harness such capacity by subjecting the female body to a "machineprocess."

${ }^{3}$ I do agree with Carol Brown that "a feminist approach to dance history" (202) has to pursue the goal to recover the "autonomous subjectivity" (203) of women dancers that often challenged or undermined gender conventions. However, I suggest that we also need to take into consideration, as in the case of New York folk dance instruction, how women and their bodies, as Brown notes, "have been engaged as subject matter and source for the creative endeavors" (203) of men.

${ }^{4}$ The exact breakdown is as follows: 2 Bohemian dances, 3 Danish dances, 4 English dances, 2 Finnish dances, 1 Hungarian, Irish, Italian, Norwegian, and Russian dance, 3 Scottish dances, and 17 Swedish dances. Gulick's family was of Dutch extraction, but no Dutch dance is on his list (HAD 246-49).

\section{Works Cited}

Armstrong, Tim. Modernism, Technology, and the Body: A Cultural History. Cambridge: Cambridge UP, 1998.

Barker-Benfield, G. J. Horrors of the Half-Known Life: Male Attitudes Toward Women and Sexuality in Nineteenth-Century America. New York: Harper \& Row, 1976.

Bederman, Gail. Manliness and Civilization: A Cultural History of Gender and Race in the United States, 18801917. Chicago: U of Chicago P, 1995.

Bourdieu, Pierre. The Logic of Practice. Trans. Richard Nice. Stanford: Stanford UP, 1990.

Brown, Carol, "Re-tracing Our Steps: The Possibilities for Feminist Dance Historians." Dance History: An Introduction. 2nd ed. Ed. Janet Adshead-Lansdale and June Layson. New York: Routledge, 1994. 198-216.

Budd, Michael Anton. The Sculpture Machine: Physical Culture and Body Politics in the Age of Empire. New York: New York UP, 1996.

Buenker, John D. "Sovereign Individuals and Organic Networks: Political Cultures in Conflict during the Progressive Era." American Quarterly 40 (June 1988): 187-204.

Butler, Judith. Bodies That Matter: On the Discursive Limits of Sex. New York: Routledge, 1992.

Diner, Steven J. A Very Different Age: Americans of the Progressive Era. New York: Hill \& Wang, 1998.

Duara, Prasenjit. "Historicizing National Identity, Or Who Imagines What and When." Becoming National: A Reader. Ed. Geoff Eley and Ronald Grigor Suny. New York: Oxford UP, 1996. 151-78.

Edwards, Rebecca. Angels in the Machinery: Gender and American Party Politics from the Civil War to the Progressive Era. New York: Oxford UP, 1997.

Foucault, Michel. Birth of the Clinic. London: Tavistock, 1973.

- Discipline and Punish. New York: Vintage, 1975.

- The History of Sexuality. Vol. 1: An Introduction. New York: Vintage, 1980.

Freedman, Estelle B., and John D'Emilio. Intimate Matters: A History of Sexuality in America. New York: Harper \& Row, 1988.

Glassberg, David. American Historical Pageantry: The Uses of Tradition in the Early Twentieth Century. Chapel Hill: U of North Carolina P, 1990.

Gorn, Elliot J. The Manly Art: Bare-Knuckle Prizefighting in America. Ithaca: Cornell UP, 1986.

Gulick, Luther Halsey. The Healthful Art of Dancing. New York: Doubleday, 1911.

Haller, John S., Jr., and Robin M. Haller. The Physician and Sexuality in Victorian America. Urbana: $\mathrm{U}$ of Illinois P, 1974. 
Halttunen, Karen. Confidence Men and Painted Women: A Study of Middle-Class Culture in America, 1830-1870. New Haven: Yale UP, 1982.

Hartsock, Nancy C. M. Money, Sex and Power: Toward a Feminist Historical Materialism. Boston: Northeastern UP, 1985.

Higham, John. Strangers in the Land: Patterns of American Nativism, 1860-1925. 2nd ed. New Brunswick: Rutgers UP, 1988.

Hopkins, C. Howard. History of the Y.M.C.A. in North America. New York: Association Press, 1951.

Kasson, John F. Rudeness and Civility: Manners in Nineteenth-Century America. New York: Hill and Wang, 1990.

Kimmel, Michael. Manhood in America: A Cultural History. New York: Free Press, 1995.

McClintock, Anne. Imperial Leather: Race, Gender and Sexuality in the Colonial Context. New York: Routledge, 1995.

Porter, Roy. "History of the Body." New Perspectives on Historical Writing. Ed. Peter Burke. Cambridge: Polity Press, 1991. 206-32.

Rader, Benjamin G. “The Recapitulation Theory of Play: Motor Behaviour, Moral Reflexes and Manly Attitudes in Urban America, 1880-1920." Manliness and Morality: Middle-Class Masculinity in Britain and America, 1880-1940. Ed. J. A. Mangan and James Walvin. New York: St. Martin's Press, 1987. 123-34.

Riess, Steven A. Sport in Industrial America, 1850-1920. Wheeling, IL: Harlan Davidson, 1995.

Rodgers, Daniel T. "In Search of Progressivism." Reviews in American History 10 (Dec. 1982): 113-32.

Rotundo, E. Anthony. American Manhood: Transformations in Masculinity from the Revolution to the Modern Era. New York: Basic Books, 1993.

Russett, Cynthia Eagle. Sexual Science: The Victorian Construction of Womanhood. Cambridge, MA: Harvard UP, 1989.

Schiebinger, Londa. Nature's Body: Gender in the Making of Modern Science. Boston: Beacon Press, 1993.

Seltzer, Mark. Bodies and Machines. New York: Routledge, 1992.
Shell, Marc. Children of the Earth: Literature, Politics, and Nationhood. New York: Oxford UP, 1993.

Shilling, Chris. The Body and Social Theory. London: Sage, 1993.

Synnott, Anthony. The Body Social: Symbolism, Self and Society. New York: Routledge, 1993.

Thomas, Helen. Dance, Modernity and Culture: Explorations in the Sociology of Dance. Routledge: New York, 1995.

Tomko, Linda J. "Fete Accompli: Gender, 'Folk Dance,' and Progressive-Era Political Ideals in New York City." Corporealities: Dancing, Knowledge, Culture and Power. Ed. Susan Leigh Foster. New York: Routledge, 1996. 156-76.

Turner, Bryan S. The Body and Society. Oxford: Basil Blackwell, 1984.

Vedery, Katherine. "Whither 'Nation' and 'Nationalism?" Mapping the Nation. Ed. Gopal Balakrishnan. New York: Verso, 1996. 226-34.

Walby, Sylvia. "Woman and Nation." Mapping the Nation. Ed. Gopal Balakrishnan. New York: Verso, 1996. 198213.

Waldby, Catherine. "Destruction: Boundary Erotics and Refigurations of the Heterosexual Male Body." Sexy Bodies: The Strange Carnalities of Feminism. Ed. Elizabeth Grosz and Elspeth Probyn. New York: Routledge, 1995. 265-77.

Wiebe, Robert H. The Search for Order, 1877-1920. New York: Hill and Wang, 1967.

Thomas Winter is currently a visiting instructor in the Department of American Culture and Literature at Bilkent University, Ankara, Turkey. He received his M.A. and his Ph.D. in American history at the University of Cincinnati. $\mathrm{He}$ is currently working on a book manuscript, titled Making Manly Men: The YMCA, Manhood and Class, 1877-1921, and editing a collection of essays, titled American Masculinities: Men and the Victorian Transformation. 